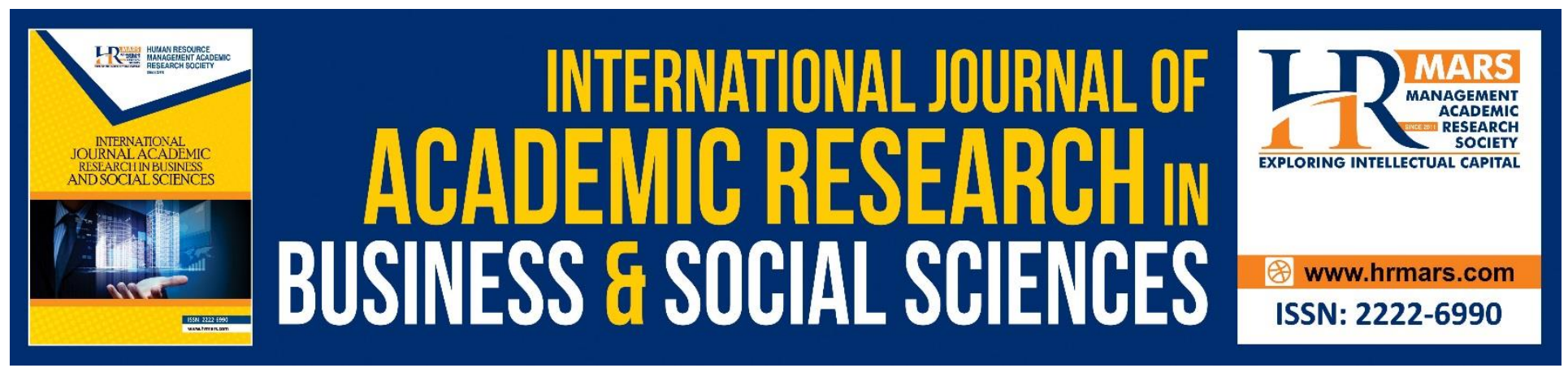

\title{
The Determinants of Public Sector Innovation in Malaysia: A Proposed Framework
}

Norasyikin Shaikh Ibrahim, Ahmad Fadzli bin Ahmad Tajuddin

To Link this Article: http://dx.doi.org/10.6007/IJARBSS/v10-i9/7646

DOI:10.6007/IJARBSS/v10-i9/7646

Received: 04 June 2020, Revised: 07 July 2020, Accepted: 19 August 2020

Published Online: 28 September 2020

In-Text Citation: (Ibrahim, \& Tajuddin, 2020)

To Cite this Article: Ibrahim, N. S., \& Tajuddin, A. F. bin. A. (2020). The Determinants of Public Sector Innovation in Malaysia: A Proposed Framework. International Journal of Academic Research in Business and Social Sciences. 10(9), 848-857.

Copyright: (C) 2020 The Author(s)

Published by Human Resource Management Academic Research Society (www.hrmars.com)

This article is published under the Creative Commons Attribution (CC BY 4.0) license. Anyone may reproduce, distribute, translate and create derivative works of this article (for both commercial and non-commercial purposes), subject to full attribution to the original publication and authors. The full terms of this license may be seen

at: http://creativecommons.org/licences/by/4.0/legalcode

\section{Vol. 10, No. 9, 2020, Pg. 848 - 857}

Full Terms \& Conditions of access and use can be found at http://hrmars.com/index.php/pages/detail/publication-ethics 


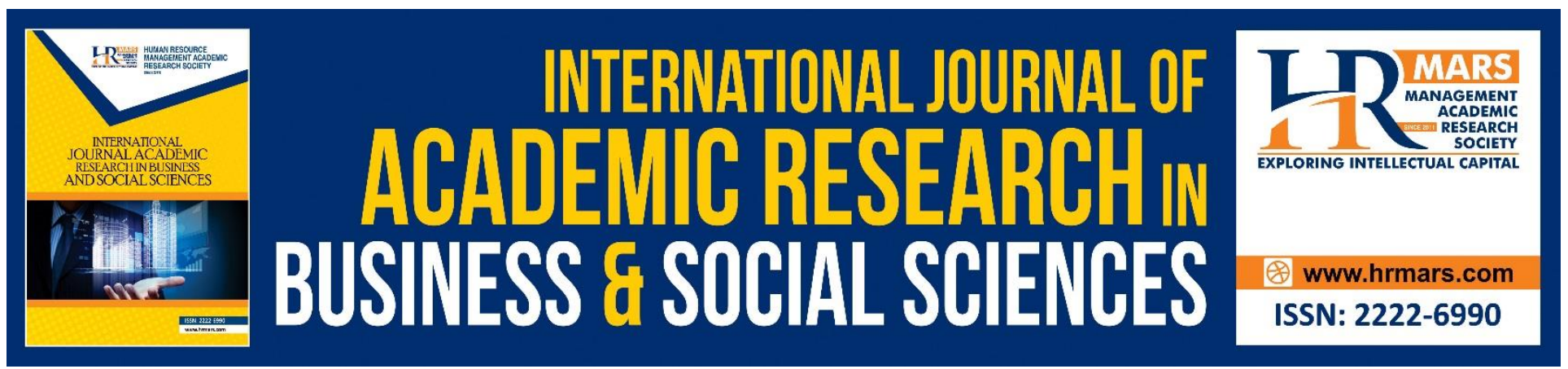

\title{
The Determinants of Public Sector Innovation in Malaysia: A Proposed Framework
}

\author{
Norasyikin Shaikh Ibrahim \\ National Institute of Public Administration Malaysia, Jalan Elmu, 59100, Kuala Lumpur. \\ Email: syikinibrahim@intanbk.intan.my \\ Ahmad Fadzli bin Ahmad Tajuddin \\ Klang Municipal Council, Malaysia, Bangunan Sultan Alam Shah, Jalan Perbandaran \\ 41675, Klang, Selangor.
}

\begin{abstract}
At present, Malaysian government are buffeted by strategic challenges including debt, deficit pressures, technology, innovation and globalization. Hence, Malaysian public service agencies recognize that they need to be resilient. In other words, they need to respond to people demand (adaptation), provide efficient and effective services (competitiveness) and make themselves reputable (value). This paper therefore aims to evaluate and suggest a conceptual model of innovative work behaviour, innovation climate, participative leadership and wider public sector condition on innovation (IVS) and innovation performance. A Structural Equation Model (SEM) was proposed. A structural relationship model was suggested. Research theories are being formulated based on the proposed conceptual model and checked. The paper ends with planned theoretical work for the future.
\end{abstract}

Keywords: Innovation, Public Sector, Climate, Leadership, Growth, Innovative Work Behavior.

\section{Introduction}

The Malaysian government is currently facing structural challenges such as debt, deficit pressures, technology, innovation and globalisation (Siddiquee, 2008; Caverley, 2005; Ramli et al., 2017). Malaysian public service organisations therefore agree that they need to be resilient (Ministry of Finance, 2018). In other words, they have to respond to demand from people (adaptation), provide effective and reliable services (competitiveness) and reputable services (value). Innovation has been identified in the 11th Malaysia Plan (2016-2020), which represents a source of growth and sustainability and serves as a key competence to achieve country status of high revenue by 2020 (Economic Planning Unit, 2016). To this end, Malaysia has initiated major changes and improvements in its sustainable development framework to reshap and restructure current public sector frameworks and processes. This is intended to increase the level of access, responsiveness and pace of public services. These are the components of the central government of people. Innovation is an 
INTERNATIONAL JOURNAL OF ACADEMIC RESEARCH IN BUSINESS AND SOCIAL SCIENCES Vol. 10, No. 9, 2020, E-ISSN: 2222-6990 @ 2020 HRMARS

integral component of the world-class public service by designing and introducing creative programmes, products and services. Innovation has been shown to lead to significant performance improvements, productivity and improved outcomes. As we move towards globalisation, Malay Public Service should increase its quality and productivity by meeting people's demands (Siddiquee, 2007).

Officials are regarded as an important tool for innovation in this field. One alternative that enhances the productivity of the public sector is to encourage innovative workers. In order to remain resilient and responsive to impredictable, dynamic and evolving circumstances, organisations must be highly creative and imaginative in sustaining their competitive advantage (Gumusluoglu \& Ilsev, 2009; Kassim \& Mokhber, 2015). Research on innovation factors in the Malaysian public sector is however limited (Ali \& Buang, 2016). There are also lack of appropriate public sector innovation assessment mechanisms (Arundel, Bloch \& Ferguson 2019). Previous innovation research appear to concentrate on business and industry, and very little has been achieved in evaluating public sector innovation. The limitations of the current world and atmosphere of progress - study to find ways to change. This paper identifies four important factors that influence innovation in Malaysia public service organization, which include innovative work behaviour, innovative culture, participative leadership and wider public sector condition for innovation. This article is divided in four parts. It starts with the introduction. Then accompanied by detailed literature review research. In third section, proposed methodology and expected outcomes will be discussed and finally, this chapter conclude the expected outcomes. The research questions that should be answered are: a) What are the determinants of Malaysian innovation especially in public sector? b) What is the relationship between respondents' demography and factors of innovation in Malaysian public sector?

\section{Literature Review}

\section{Innovative Work Behaviour}

Innovative work behavior or IWB is defined as "employee behavior to intentionally create, introduce and apply new ideas within a work role, group or organization that is beneficial to performance" (Janssen, 2000, p. 288). Several dimensions of innovation can be identified within the framework of the concept of IWB. It begins with the generation of ideas. While the terms "idea generation" and "creativity" are used conversely, the author pick for 'idea generation' as it is near to innovative work behavior literature (Janssen, 2000; Jong \& Hartog, 2008; Scott \& Bruce, 1994).

Employees consider challenges and opportunities and pursue solutions for new ideas. Mumford (2000) described idea generation as "a free-flowing activity where application, implication, and consequences are identified and then shaped through refinement into a new idea or set of ideas".

The second dimension is the preservation of ideas. The business welcomes the concept of financing for further expansion. Help is to construct coalitions of potential allies - people who exercise the idea - by expressing trust and arousal for the advancement, participation and involvement of the right people (De Jong and Den Hartog, 2010; Galbraith, 1982; Janssen, 2000; Kanter, 1988). This could include superiors, other officials, such as R\&D, or immediate colleagues. Idea championing after all to get support with the ideas generated and to engage key business members in job ideas.

The third dimension, the application of ideas, focuses on the introduction into daily business of ideas created and promoted (Kleysen \& Street 2001) and on the inclusion of such ideas discovered and 
INTERNATIONAL JOURNAL OF ACADEMIC RESEARCH IN BUSINESS AND SOCIAL SCIENCES Vol. 10, No. 9, 2020, E-ISSN: 2222-6990 @ 2020 HRMARS

realised on the workplace, community or organisation (Janssen, 2000; R. Kanter, 1988). The two final aspects, the defence of ideas and the application of ideas, are also defined as jointly applicable.

Innovative past working behaviour generally considered this to be one aspect consisting of many behaviours (e.g. Janssen, 2000; Park \& Jo, 2018; Shanker et al . , 2017). For different behavioural sets IWB can be used as a single dimensional container. These behavioural sets represent our aspects of developing ideas, defending ideas and executing ideas. A detailed picture of the contributions individuals make to organisational performance by conceptualising IWB in various behavioural sets. For example, the development of ideas alone does not guarantee the acceptance of those ideas, because new ideas can lead to uncertainty and resistance to changes (Baer, 2012; West, 2002). Furthermore, the three dimensions (idea formation, ideas championship and ideas implementation) involve different working styles, different employee personal characteristics and different behaviours (Scott \& Bruce 1994; Street \& Christopher 2001). According to Scott and Bruce (1994, p. 582), imagination is a dynamic process, not a single aspect but a 'discontinuous activity' (Veenendaal \& Bondarouk, 2015).

\section{Innovation Climate}

The organisational environment is a significant factor in innovation based on previous studies (Isaksen \& Lauer, 2002). Nystrom (1990) described the environment as "the occurrence and repetition of behavioural patterns, attitudes and sensations that characterise the organisation 's life." It is also closely related to an organisational culture that transmits "beliefs and principles, traditions, tales, rituals and ceremonies and the organisation' (Tesluk et al., 1997). Climate can therefore be described as "a series of attributes that can be influenced by the way the organisation deals with their members and their environment." The author will follow the most generally accepted and proven climate innovation model in this study (Anderson \& West, 1998; Siegel \& Kaemmerer, 1978). Based on this model, three fundamental dimensions of climate innovation, including participatory security, quality and support for innovation, will be explored further.

The initial component of climate innovation is participatory security. De Jong (2006) states that when workers view the behaviour and behaviours of their colleagues in ways that facilitate learning, they safeguard their well-being and interests, an organisation receives good socio-emotional support. The theory is that employees are driven by decision-making and regard the world as non-personal (West, 1990). It is considered one of the facets of the atmosphere of innovation. This will then encourage risk-taking and the readiness of the employee to present new ideas without fear. Participatory security often encourages workers' understanding of self-decision, which contributes to a broader job satisfaction than negative conditions that regulate their thoughts, feelings and actions. It allows scientists to conclude that participatory safety is a healthy environment which supports and makes a company's employees creative and innovative.

The second element of climate creativity relates to the quality of group members' task results. In highly innovative climates, high performance standards are encouraged and different approaches to quality are embraced. The pursuit of excellence can be defined as maximising the performance of tasks according to West (1990). Additional research was carried out, and this innovative environment aspect was referred to as the "job orientation," which proposed that staff analyse their current 
activities and proactively incorporate improvements (Anderson \& West, 1998). For this reason, the pursuit of excellence can be called the success by working processes between members of the working group of a task with a better quality result. Innovation support for endorsing and encouraging realistic proposals to incorporate innovative and better ways to do things (West 1990). This is the final dimension.

Innovation support as examples are expressed support inside and outside group meetings and collaboration in the development and implementation of new ideas. Time and resources have also been given for community members to formulate and execute ideas. If innovation support is regularly expressed and incorporated in a working group, members in the working group are more aware of the situation under their influence and are more likely to improve. (Gebert et al . , 2003). According to past studies, the person should be alert of the potential of innovation in promoting innovation so they can provide suggestions more readily when resources and help for other members of the working group are accessible to them. These studies show that the climate of innovation, including participatory safety, the pursuit of excellence and the promotion of innovation dimensions, have a positive impact on innovation.

\section{Participative Leadership}

Participatory leadership is a shared power and decisions between a leader and his followers (Armenakis et al . 1993), intended to increase influence, extra care and support among followers and their engagement in problem solving and decision-making (Nystrom, 1990). Participatory leadership suggests to workers that their boss has faith in them, and several studies indicate that participatory leadership has significant effects on different performance styles, including innovation and creative actions (Huang et al., 2006; Weng et al., 2013). While participatory leaders include workers in problem-solving and decision-making processes (Newman et al . , 2018), they do not necessarily include the clear role modeling and feedback that will enable those workers to be more confident in their creative capacity (i.e., high CSE levels) and engage in innovative behaviour (Newman et al., 2018).

\section{Wider Sector Conditions for Innovation}

This variable explains how the world in which an company works makes progress possible or impeded by the following:

- Leadership and culture, e.g. vision and spirit of innovation; strategy-related innovation; risk-taking and learning attitudes; attentiveness to users' opinions, front-line workers and middle managers; attitudes towards collaboration/working across organizational boundaries; emphasis on short/medium/long-term goals; and efficiency of new initiatives.

- Autonomy, e.g. accountability for creativity, flexibility in shaping local policy, flexibility in budgetary matters, ability to draw up rules and provide direction and legislative basis.

Incentives, such as demand, competitiveness, performance goals, transparency in results, customer engagement, acknowledgement and incentives, and regulation.

- Enablers, for example, access to open comparable performance data, access to best practices information in the private and public sectors, access to and funding for innovation funds, award schemes, learning from inspections / audits, access to common systems and resources, sufficient knowledge and communication infrastructure, peer review processes and innovation measurement; 
INTERNATIONAL JOURNAL OF ACADEMIC RESEARCH IN BUSINESS AND SOCIAL SCIENCES Vol. 10, No. 9, 2020, E-ISSN: 2222-6990 @ 2020 HRMARS

In particular, the impact of a wider business situation on the development of inventions is 0.001 . This finding reinforces the results of past studies which examine the influence of external performance on the performance of government innovation such as Moon and Bretschneider (2002), Walker (2006), and Hansen (2011). Based on the studies performed, the results of a rigorous evaluation of broader public sector innovation showed that the total number was 5,1009 (moderately high total). The result showed that the output of public sector innovation was influenced by a medium mean innovation score from a wider industry (Ramli et al . 2017).

\section{Methodology}

In this analysis, a formal questionnaire will be used for the method of sampling. The Malaysian public servants will be the population. Questions will be provided to public servants, particularly the Ministry and State Government Innovation Unit, innovators and non-innovators and middle and senior managers. To evaluate the effects, two statistical methods were used. Techniques for structural equation modelling will be employed to carry out the necessary statistical analyses of the results of the survey. In order to determine the packing, durability and measurements of the system, an analysis of exploratory factors, reliability analysis and confirmatory factor analysis will be performed. After evaluation of the measurement model, the structural model will then be evaluated and validated. Version 26 of SPSS will be used to review preliminary data and to conduct thorough analysis of the sample of theses, such as means, standard deviations and frequencies. In comparison, SEM is evaluated for the measurement model using SMART-PLS.

\section{Proposed Research Model}

Based on the literature review, a significant number of previous studies have been performed, i.e. Innovative work behaviour, Innovation environment for wider public service, Participatory Leadership and Innovation Success (IP). The research seeks to analyse the relationship between independent variables and an organisation's performance in innovation. This model is referred to as the proposed study model, as shown in Figure 1. 
INTERNATIONAL JOURNAL OF ACADEMIC RESEARCH IN BUSINESS AND SOCIAL SCIENCES Vol. 10, No. 9, 2020, E-ISSN: 2222-6990 @ 2020 HRMARS

Figure 1: Proposed research model.

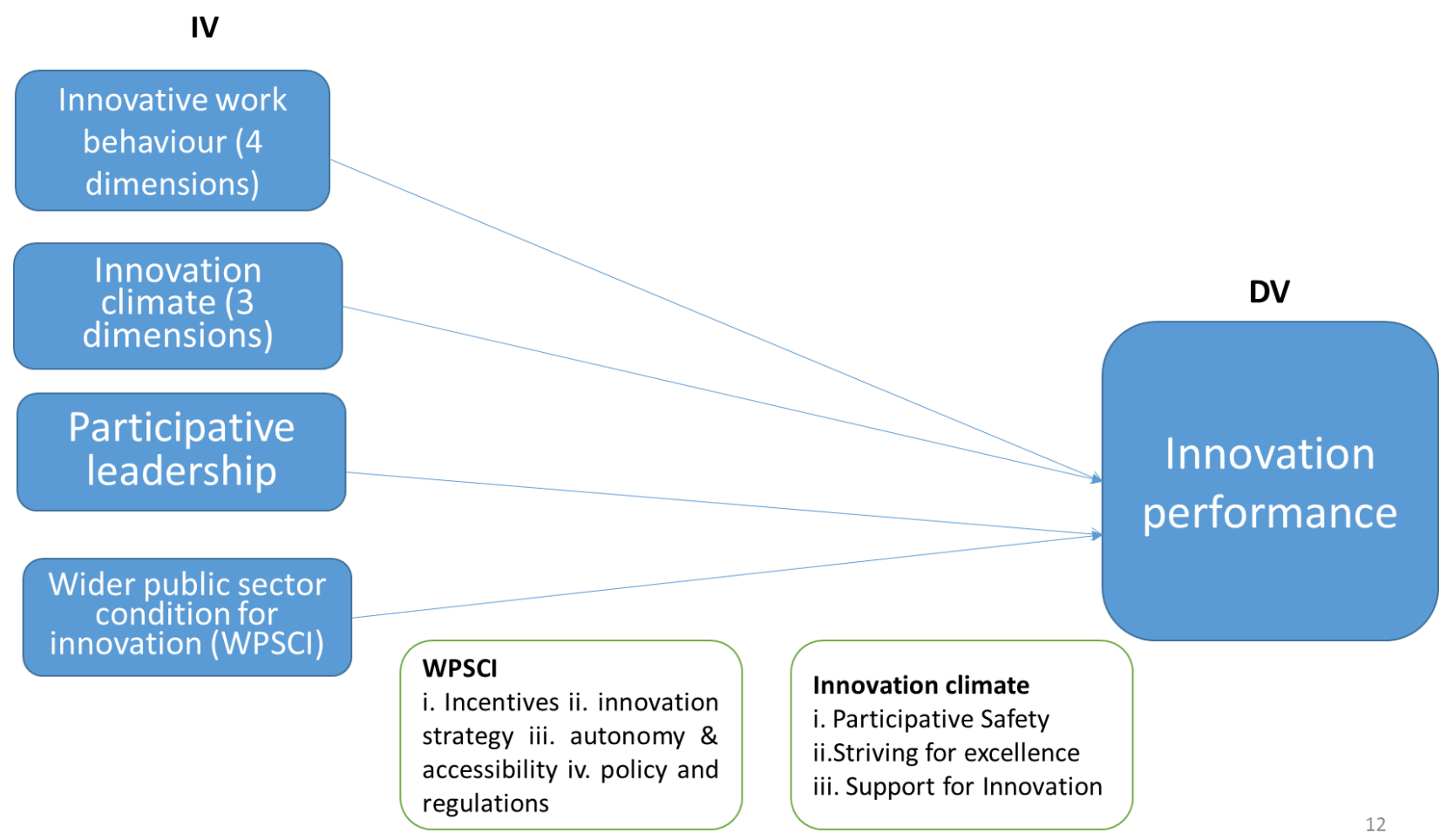

Source: Author's proposed model.

\section{Conclusion and Future Research}

For IP, IWB, IC, PL and WPSCI have become the most important ones. Previous studies were conducted to identify reasons for the successful implementation of results in innovations. However, in particular in the Malaysian Public Sector, minimal empirical research attempted to investigate the relationship between the IVs and success in innovation. Research hypotheses are being build, based on the proposed model and a previous analysis. The next step of this study is to develop instruments which will be used in the Malaysian public sector for pilot study data collection.

\section{Corresponding Author}

Norasyikin Shaikh Ibrahim, PhD

Cluster of Management Development and Innovation

National Institute of Public Administration

Jalan Elmu, 59100, Kuala Lumpur.

Email: syikinibrahim@intanbk.intan.my; noraderinda@gmail.com

\section{References}

Siddiquee, A. N. (2008). Service delivery innovations and governance: The Malaysian experience. Transforming Government: People, Process and Policy, 2(3), 194-213. https://doi.org/10.1108/17506160810902194

Ali, K. A. M., \& M. Buang. (2016). Study on Factors that Influence Innovation in Malaysian Public Sector. Journal of Advanced Research in Business and Management Studies, 4(2016), 60-73. 
INTERNATIONAL JOURNAL OF ACADEMIC RESEARCH IN BUSINESS AND SOCIAL SCIENCES

Vol. 10, No. 9, 2020, E-ISSN: 2222-6990 @ 2020 HRMARS

Anderson, N. R., \& West, M. A. (1998). Measuring climate for work group innovation: Development and validation of the team climate inventory. Journal of Organizational Behavior, 19(3), 235258.

Arundel, A., Bloch, C., \& Ferguson, B. (2019). Advancing innovation in the public sector : Aligning innovation measurement with policy goals. Research Policy, 48(3), 789-798. https://doi.org/10.1016/j.respol.2018.12.001

Caverley, N. (2005). Civil Service resiliency and coping. International Journal of Public Sector Management, 18(5), 401-413. https://doi.org/10.1108/09513550510608868.

Armenakis, A. A., Harris, S. G., \& Mossholder, K. W. (1993). Creating Readiness for Organizational Change. Human Relations. https://doi.org/10.1177/001872679304600601

Caverley, N. (2005). Civil Service resiliency and coping. International Journal of Public Sector Management, 18(5), 401-413. https://doi.org/10.1108/09513550510608868

De Jong, J. P. J. (2006). Individual Innovation: The Connection Between Leadership and Employees' Innovative Work Behavior. In Scales Research Reports. https://doi.org/10.1177/1745691612459060.

Galbraith, J. R. (1982). Designing the innovating organization. Organizational Dynamics. https://doi.org/10.1016/0090-2616(82)90033-X

Gebert, D., Boerner, S., \& Lanwehr, R. (2003). The risks of autonomy: Empirical evidence for the necessity of a balance management in promoting organizational innovativeness. Creativity and Innovation Management. https://doi.org/10.1111/1467-8691.00267

Gumusluoglu, L., \& Ilsev, A. (2009). Transformational leadership, creativity, and organizational innovation. Journal of Business Research, 62(4), 461-473.

https://doi.org/10.1016/j.jbusres.2007.07.032

Hansen, M. B. (2011). Antecedents of Organizational innovation: The diffusion of new public management into Danish local government. Public Administration, 89(2). https://doi.org/10.1111/j.1467-9299.2010.01855.x

Huang, I.-C., Lin, H.-C., \& Chuang, C.-H. (2006). Constructing factors related to worker retention. International Journal of Manpower, 27(5), 491-508.

https://doi.org/10.1108/01437720610683976

Isaksen, S. G., \& Lauer, K. J. (2002). The climate for creativity and change in teams. Creativity and Innovation Management. https://doi.org/10.1111/1467-8691.00238

Janssen, O. (2000). Job demands, perceptions of effort-reward fairness and innovative work behaviour. Journal of Occupational and Organizational Psychology. https://doi.org/10.1348/096317900167038

Jong, J. P. J. D., \& Hartog, D. N. Den. (2008). Innovative Work Behavior : Measurement and Validation. Scientific Analysis of Entrepreneurship and SMEs.

Kanter, R. (1988). When a thousand flowers bloom: structural, collective, and social conditions for innovation in organizations. Research in Organizational Behaviour, 10(169).

Kassim, S. M., \& Mokhber, M. (2015). Improving Employee Outcome through Human Resource Management Practices and Public Service Motivation: A Study of Malaysia Public Sector. Journal of Advanced Review on Scientific Research, 11(1), 1-12.

Kleysen, R. F., \& Street, C. T. (2001). Toward a multi-dimensional measure of individual innovative behavior. Journal of Intellectual Capital. https://doi.org/10.1108/EUM0000000005660

Moon, M. J., \& Bretschneider, S. (2002). Does the Perception of Red Tape Constrain IT Innovativeness 
INTERNATIONAL JOURNAL OF ACADEMIC RESEARCH IN BUSINESS AND SOCIAL SCIENCES

Vol. 10, No. 9, 2020, E-ISSN: 2222-6990 @ 2020 HRMARS

in Organizations ? Unexpected Results from a Simultaneous Equation Model and Implications. Journal of Public Administration Research and Theory, 12(1993), 273-291.

Mumford, M. D. (2000). Managing Creative People: Strategies and Tactics for Innovation. Human Resource Management Review. https://doi.org/10.1016/S1053-4822(99)00043-1

Newman, A., Tse, H. H. M., Schwarz, G., \& Nielsen, I. (2018). The effects of employees' creative selfefficacy on innovative behavior: The role of entrepreneurial leadership. Journal of Business Research, 89(September 2016), 1-9. https://doi.org/10.1016/j.jbusres.2018.04.001

Nystrom, H. (1990). Organizational Innovation. In: West, M.S. and Farr, J.L., Eds., Innovation and Creativity at Work: Psychological and Organizational Strategies, Wiley, New York, 143-162.

Park, S., \& Jo, S. J. (2018). The impact of proactivity, leader-member exchange, and climate for innovation on innovative behavior in the Korean government sector. Leadership and Organization Development Journal, 39(1), 130-149. https://doi.org/10.1108/LODJ-09-20160216

Ramli, R. I., Hassan, N. A., Arifin, A. S., \& Jasmi, A. N. (2017). Factors Influencing Public Sector Innovation Performance in Malaysia : Structural Equation Modelling Approach. International Journal of Academic Research in Business and Social Sciences, 7(2), 629-645. https://doi.org/10.6007/IJARBSS/v7-i2/2671

Scott, S. G., \& Bruce, R. A. (1994). Determinants of Innovative Behavior: A Path Model of Individual Innovation in the Workplace. Academy of Management Journal. https://doi.org/10.5465/256701

Shanker, R., Bhanugopan, R., van der Heijden, B. I. J. M., \& Farrell, M. (2017). Organizational climate for innovation and organizational performance: The mediating effect of innovative work behavior. Journal of Vocational Behavior, 100, 67-77. https://doi.org/10.1016/j.jvb.2017.02.004

Siddiquee, N. A. (2008). Service delivery innovations and governance: The Malaysian experience. In : Transforming Government: People, Process and Policy, 2(3), 194-213.

https://doi.org/10.1108/17506160810902194

Siddiquee, N. (2007). Public service innovations, policy transfer and governance in the Asia-Pacific region: The Malaysian experience. 2(1), 81-91.

Siegel, S. M., \& Kaemmerer, W. F. (1978). Measuring the perceived support for innovation in organizations. Journal of Applied Psychology. https://doi.org/10.1037/0021-9010.63.5.553

Smith, G. P. (2002). The new leader: Bringing creativity and innovation to the workplace.

Street, C. T. K. F. R., \& Christopher, T. S. (2001). Toward a multi-dimensional measure of individual innovative behavior. Journal of Intellectual Capital, 2(3), 284-296. http://dx.doi.org/10.1108/EUM0000000005660

Tesluk, P. E., Farr, J. L., \& Klein, S. R. (1997). Influences of organizational culture and climate on individual creativity. Journal of Creative Behavior, 31(1), 27-41. https://doi.org/10.1002/j.2162-6057.1997.tb00779.x

Veenendaal, A., \& Bondarouk, T. (2015). Innovation Networks Perceptions of HRM and their effect on dimensions: Evidence from a manufacturing firm. Management Revue, 26(2), 139-159. https://doi.org/10.1688/mrev-2015-02-

Walker, R. M. (2006). Innovation type and diffusion : An Empirical Analysis of local government. Public Administration, 84(2), 311-335.

Weng, R., Huang, C., Chen, L., \& Chang, L. (2013). Exploring the impact of transformational leadership 
INTERNATIONAL JOURNAL OF ACADEMIC RESEARCH IN BUSINESS AND SOCIAL SCIENCES Vol. 10, No. 9, 2020, E-ISSN: 2222-6990 @ 2020 HRMARS

on nurse innovation behaviour: a cross-sectional study. Journal of Nursing Management. https://doi.org/10.1111/jonm.12149

West, M. A. (1990). The social psychology of innovation in groups. In Innovation and creativity at work: Psychological and organizational strategies. 